\title{
Institutional Ownership, Political Connestions and Dividend Payment
}

\author{
Ratna Yunita $^{\bowtie}$, Arief Yulianto \\ Management Department, Faculty of Economics, Universitas Negeri Semarang, Semarang, Indonesia
}

\author{
Article Information \\ Article History: \\ Received January 2020 \\ Approved February 2020 \\ Published March 2020 \\ Keywords: \\ Institutional Ownership, \\ Political Connection, \\ Dividen Policy.
}

\begin{abstract}
This study aims to examine the effect of institutional ownership and differences in the average dividend payout policy in the presence of a political connection variable. The population in this study are all companies listed on the Indonesia Stock Exchange in 2008-2017. The sample in this study was based on purposive sampling. The sample of this study were 1157 observations. The analytical method used is a dummy covariance analysis (ANCOVA) regression model. The results showed that institutional ownership had a coefficient value of 0.039768 . political connections have a coefficient value of 0.042068 . That is, institutional ownership and political connections have a positive influence on dividend payment policies in Indonesia.
\end{abstract}

\section{INTRODUCTION}

Ahmad and Wardani (2014) dividends are payments from company income or profits distributed to shareholders in cash or longer shares. In addition, the distribution of dividends is also considered reciprocity of the proportion of share ownership by investors. Each company certainly has its own policy in determining the distribution of dividends. For this reason, careful consideration is needed in relation to dividend policy, with the form, percentage and stability of dividends distributed (Sari \& Wijayanto, 2015).

Companies must strive to make dividend policies that will maximize the welfare of shareholders (Miller \& Modligiani, 1961). Conversely, companies do not want a high dividend distribution. That is because the high dividend distribution, the lower the funds under management (Anita \& Yulianto, 2016). In agency theory that explains the working relationship between company owners (shareholders) and managers / ma- nagement. Management is an agent appointed by the shareholders or often referred to as the principal, who is given the task and authority to manage the company on behalf of the shareholders. But often the interests between management and the interests of shareholders are in conflict, this is what causes an agency conflict. Supported by statements that managers often act in certain interests and ignore the interests of other shareholders (Yulianto et al., 2014).

Agency conflict is a problem that arises due to a conflict of interest between the manager (agent) and the shareholders (company owner) due to the separation of the company's management duties from the shareholders (Keown, 2008). Agency problems are also caused due to investment mistakes or misuse of income by managers (Erfiana \& Ardiansari, 2016). McKnight and Weir (2009) said institutional ownership as a method for monitoring management behavior. That means in addition to dividend distribution and ownership is one of the methods used to mo-

(C) 2019 Universitas Negeri Semarang

\footnotetext{
Correspondence Address:

L2 Building, 1st Floor, Faculty of Economics, Universitas Negeri Semarang

Jalan Taman Siswa, Sekaran, Gunungpati, Semarang, 50229

E-mail: ratnayunita1997@gmail.com
} 
nitor company management. The definition of institutional ownership or institutional investors according to Jannah and Khoiruddin (2017) is a company stock owned by an institution.

Institutional ownership can reduce agency costs, because they can monitor company performance and can influence managerial decision making (Sajid et al., 2012). Pratiwi and Yulianto (2016) institutional shareholders can also intervene directly in order to reduce agency costs because they have greater power to influence decision making and operational activities of the company.

High institutional ownership will result in stricter supervision efforts, which can limit the behavior of managers who use opportunities only to benefit their personal interests (Scott, 2000). Prasetyo (2013) results that institutional ownership has a positive effect on dividends. Meckling (1986) looks at agency problems from the point of view of the availability of money that managers can use for consumptive activities, these funds are free cash flow, which is excess funds in the company after all investment projects that generate positive net present value are implemented. Yulianto et al. (2015) said companies that benefit and increase the likelihood that investment will pay dividends, so companies that pay good dividends, can choose funding sources that come from profits or from debt.

Supported by Abiprayu and Wiratama (2016) the conditions that must be met in order for a company to distribute dividends is that the company must have a positive net income. While there are several factors that can determine the level of company income, one of which is the investment opportunities owned by the company. Then Roberto (2002) also mentions that investment opportunities are one of the factors that influence the company's dividend policy. Investment opportunities are closely related to the network owned by the company. One that can strengthen a company's business network is a political connection with the authorities (Setiawan, 2014). Political connection can have a kind of positive impact on the company, such as expediting business affairs.

Goldman et al. (2013) mention that having political connections makes it easy to obtain projects, so that it becomes a better business opportunity. Ardiansari and Saputra (2015) also stated that political conditions, directly or indirectly, would influence the economic situation of a country. According to Vermonte (2012) political party funding in Indonesia is not enough just from the contributions of party members, parties also need other sources of funding from corpo- rate or individual donations which often involve transactional agreements.

\section{Hypothesis Development}

Research by Han (1999), Murhadi (2010) and Firth et al. (2016) found a positive influence between institutional ownership on dividend policy. Basically, institutional ownership will increase supervision of company management because it considers institutions as professionals who are considered to have the ability to evaluate the company concerned (Murhadi, 2010). Likewise what Wahab et al. (2009) said showed that audit fees that served were higher in companies with greater institutional ownership, reflecting demand for higher audit quality.

Eckbo and Verma (1994) argue that institutional investors prefer cash flow free (free cash flow) to be distributed in the form of dividends to reduce agency costs. In line with research belonging to Grinstein and Michaely (2005) argues that if institutional shareholders are well monitored, there must be a positive relationship between dividend payments and institutional share ownership. This is in line with agency theory in which there are often conflicts of interest, institutional ownership in some studies can be a conflict resolution, especially regarding the determination of dividend policy.

$\mathrm{H} 1$ : Institutional ownership has a positive effect on dividend policy

Setiawan (2014) said that research on political connections owned by companies is rarely associated with dividend policy. However, there are some studies that show that companies that have political connections will have a company future that is at least better. With a better future, the company will tend to provide large dividends to shareholders. As stated by Su et al. (2014) that by having a political connection the company will have more free cash flow in the future. This can be a signal to the market by distributing large dividends.

Cooper et al. (2010) also in their research found that companies that contracted positively and significantly in the political world received good stock returns in the future. In line with research Johnson \& Mitton (2003) conducted research in Malaysia and concluded that companies connected with the prime minister at that time had high stock returns as well. Su et al. (2014) have shown that companies in China compare companies that have political connections to share a greater amount of dividends compared to companies that do not have political connections. 
Companies that have political connections will find it easier to get contracts from the ruling government, compared to companies that do not have political connections with the ruling government (Goldman et al., 2009). That way, it can be concluded that if a company has political connections, it will be easier to get tenders from the government which will certainly increase revenue and free cash flow for the company. It is expected that from the increase in free cash flow the company will distribute more dividends.

$\mathrm{H} 2$ : Political connections has a positive effect on dividend policy

Based on the elaboration of previous research, it can be determined the framework of thinking about the influence of independent variables on the dependent variable as follows:

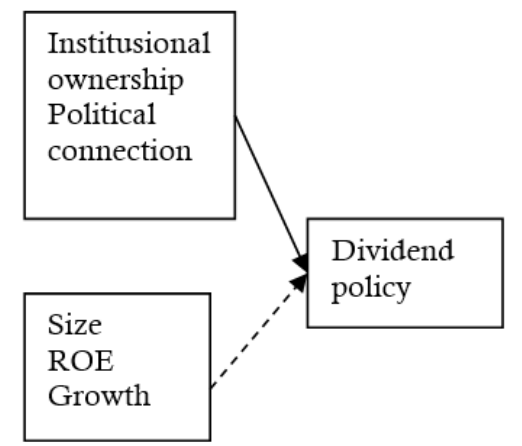

Figure 1. Research Model information :

$\longrightarrow$ - $\rightarrow$ independent variable

$---\rightarrow$ control variable

\section{METHOD}

This type of research is seen from the objectives included in explanatory research. This research uses a quantitative research approach. The type of

Table 1. Sampling Criteria data used in this study is secondary data. The data in this study were obtained from the company's financial statements in 2008-2017 and from the Indonesia Capital Market Directory (ICMD). The type of data used is unbalanced panel data because the number of observations each time is different.

The population in this study were all companies listed on the Indonesia Stock Exchange in 2008-2017 as many as 573 companies. In this study, which included a sample of 283 companies in 2008-2017. The sampling technique in this study is the purposive sampling method. In processing and analyzing data in this study, researchers used Eviews 9 data processing software.

In this study there are one dependent variable, two independent variables and 3 control variables. The dependent variable of research is proxied by the DPR. Dividend payout which is the ratio of earnings paid by companies as dividends to investors over a certain period (Nisa, 2017). The formula used to measure this ratio is:

Dividen payout ratio $=$ Dividen per Share (DPS)/(Earning per Share (EPS)

There are two independent variables in this study, namely the first institutional ownership variable and the second is the political connection variable (dummy variable). Institutional ownership is the amount of share ownership by institutional investors from outside the company (Nisa, 2017). Institutional ownership can be calculated using the formula:

INS $=($ institusional owned share $) /($ shares outstanding $) \times 100$

Political connections are measured by dummy variables, if the connected political company is worth 1 , and if it is not 0 .

\begin{tabular}{|c|c|c|c|c|c|c|c|c|c|c|c|c|}
\hline \multirow{2}{*}{ No. } & \multirow{2}{*}{ Criteria } & \multicolumn{11}{|l|}{ Year } \\
\hline & & 2008 & 2009 & 2010 & 2011 & 2012 & 2013 & 2014 & 2015 & 2016 & 2017 & Total \\
\hline 1 & $\begin{array}{l}\text { Companies } \\
\text { Listed on BEI } \\
\text { Period 2008- } \\
2017\end{array}$ & 395 & 399 & 405 & 430 & 450 & 460 & 463 & 511 & 518 & 573 & 4604 \\
\hline 2 & $\begin{array}{l}\text { Companies not } \\
\text { distributing } \\
\text { dividen during } \\
2008-2017\end{array}$ & (245) & (252) & $(260)$ & (249) & (248) & (291) & (374) & (333) & (319) & (304) & (2875) \\
\hline \multirow[t]{2}{*}{3} & Outlier Data & (43) & $(38)$ & (56) & $(58)$ & $(41)$ & (70) & $(37)$ & (58) & (79) & (92) & (572) \\
\hline & Total Obs. Unit & 107 & 109 & 89 & 123 & 161 & 99 & 52 & 120 & 120 & 177 & 1157 \\
\hline
\end{tabular}


In this study there are 3 control variables, namely ROE, company size (growth) and growth (growth). In this study ROE is the proxy chosen to measure profitability. The ROE formula is:

$$
\mathrm{ROE}=(\text { Net profit }) /(\text { equity }) \times 100
$$

Firm size is a scale, which can be classified the size of the company according to various ways, including: total assets, log size, market value of shares and others (Ridloah, 2010). Company size formula $=\ln$ (total assets). Growth is an opportunity the company has to increase the profitability of current product lines or benefit from new products or market expansion (Shapiro, 1991). Company growth formula:

total aset $\mathrm{t}-1$

Growth $=($ total assets t1-total assets $\mathrm{t}-1) /$ RESULTS AND DISCUSSION

Table 2. Descriptive Statistic extreme data that can cause bias to the results of the study or it can be said that the ROE data is normally distributed.

The average firm size value is 15.28358 which means that the average company listed on the Indonesia Stock Exchange in 2008-2017 has a firm size value of $1528 \%$, which is calculated using the total ownership of the company's assets. With a standard deviation of 1.853673 . If seen from the average value which is higher than the standard deviation value, it means that there is no deviation in the data. The average growth value is 1.60559 which means that the average company listed on the Indonesia Stock Exchange in 20082017 has a growth value of $160 \%$, which is calculated using the total ownership of the company's assets. With a standard deviation of 0.160818 . If seen from the average value which is higher than the standard deviation value, it means that there is no data deviation and there is no extreme data that can cause bias in the research results.

\begin{tabular}{llllll}
\hline & DPR & INS & ROE & SIZE & GROWTH \\
\hline Mean & 0.264403 & 0.577705 & 0.156501 & 15.28358 & 1.60559 \\
Maximum & 0.600300 & 0.982700 & 0.497100 & 20.84216 & 0.654874 \\
Minimum & 0.003300 & 0.003000 & -0.054000 & 9.517825 & -0.343801 \\
Std. Dev. & 0.127561 & 0.262313 & 0.094980 & 1.853673 & 0.160818 \\
Obs. & 1157 & 1157 & 1157 & 1157 & 1157 \\
\hline
\end{tabular}

Based table 2, the DPR's average score is 0.264403 , which means that the average company listed on the Indonesia Stock Exchange in 2008-2017 that paid dividends has a dividend payout ratio of $26 \%$. With a standard deviation of 0.127561 . Standard deviation values that are smaller than the average value indicate that the observations do not have extreme data that can cause bias to the results of the study or it can be said that the dividend payout ratio data is normally distributed. The average value of institutional ownership is 0.577705 , which means that the average company listed on the Indonesia Stock Exchange in 2008-2017 has a total institutional ownership of $57 \%$. With a standard deviation of 0.262313 . If seen from the average value which is higher than the standard deviation value, it means that there is no deviation in the data. The average $\mathrm{ROE}$ value is 0.156501 which means that the average company listed on the Indonesia Stock Exchange in 2008-2017 has a ROE value of $15 \%$. With a standard deviation of 0.094980 . Standard deviation values that are smaller than the average value indicate that in the observation there is no

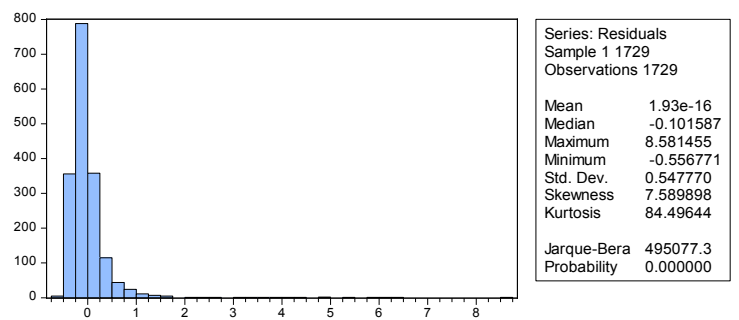

Figure 2. Normality Test Before Outlier

Based on the picture of normality test results, it can be seen a jarque value of 495077.33 with a probability value of $0.000000<0.05$ which means that $\mathrm{HO}$ is rejected. So that this data is not normally distributed. One way that can be done so that the data is normally distributed is by removing a number of data that become outlier (outlier) or disruptors in the model. Based on the results of data processing conducted, there were 572 observations that became outliers. If the data is not removed, it will damage the results of this study. The following pictures are the results of normality tests after the outlier: 


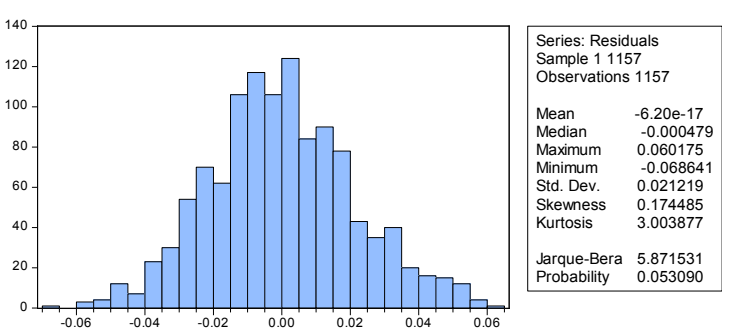

Figure 3. Normality Test After Outlier

Based on the picture above normality test results that have been done outlier data, it can be seen that the fallow jar value of 5.871531 with a probability of $0.053090>0.05$ which means that Ho is accepted, thus it can be concluded that the data can be normally distributed after the data outlier is performed. was no heteroscedasticity by looking at the value of Obs * R-squared of 8.266158 with Chi-square Probalitas 0.1422> 0.05 (5\%).

Table 5. Goodness of Fit Test

\begin{tabular}{ll}
\hline R-squared & 0.143698 \\
Adjusted R-squared & 0.139978 \\
F-statistic & 38.63036 \\
Prob(F-statistic) & 0.000000 \\
\hline
\end{tabular}

Based on table 5. can be seen the results of the coefficient of determination test, the value of $\mathrm{R} 2$ is 0.143698 . It can be said that $14 \%$ of the dependent variable is proxied by the DPR (dividend payout ratio) which can be explained by indepen-

Table 3. Multicolinearity Test

\begin{tabular}{lllllll}
\hline & DPR & PCON & INS & ROE & SIZE & GROWTH \\
\hline DPR & 1.000000 & 0.166750 & -0.046643 & 0.235867 & 0.185398 & -0.159135 \\
PCON & 0.166750 & 1.000000 & -0.469027 & 0.132771 & 0.347243 & 0.060874 \\
INS & -0.046643 & -0.469027 & 1.000000 & -0.109059 & -0.307443 & -0.035330 \\
ROE & 0.235867 & 0.132771 & -0.109059 & 1.000000 & 0.099342 & 0.214990 \\
SIZE & 0.185398 & 0.347243 & -0.307443 & 0.099342 & 1.000000 & 0.045789 \\
GROWTH & -0.159135 & 0.060874 & -0.035330 & 0.214990 & 0.045789 & 1.000000 \\
\hline
\end{tabular}

Based on the multicolinearity test results using the correlation coefficient produces output in table 4.3. which can be concluded if there is not a large enough correlation coefficient. Even the value of all the correlation coefficients between the independent variables is still below the requirement for multicollinearity that is equal to 0.90 (Ghozali and Ratmono, 2013). Based on the above results, it can be concluded if there is no high correlation between independent variables or in other words there is no multicollinearity in the data.

Table 4. Heteroskedasticity Test

\begin{tabular}{llll}
\hline \multicolumn{4}{l}{ Heteroskedasticity Test: Glejser } \\
\hline F-statistic & 1.656493 & Prob. F(5.1151) & 0.1423 \\
Obs*R- & 8.266158 & $\begin{array}{l}\text { Prob. Chi- } \\
\text { squared }\end{array}$ & 0.1422 \\
$\begin{array}{lll}\text { Scaled } \\
\text { explained }\end{array}$ & 9.234452 & $\begin{array}{l}\text { Prob. Chi- } \\
\text { SS }\end{array}$ & 0.1001 \\
\hline
\end{tabular}

Based on table 4.4 the results of heteroscedasticity test output using glacier above, there dent variables (political connections and institutional ownership) and control variables which are proxied by size, ROE and growth. The test results above explain that the calculated $F$ value of 38.63036 with a probability of $0.000000<0.05$, then the independent variable and the control variable simultaneously influence the independent variable which is proxied by the dividend payout ratio (DPR).

Table 6. Result of t Test

\begin{tabular}{lll}
\hline Variable & Coefficient & Prob. \\
\hline C & 0.050272 & 0.1405 \\
PCON & 0.042068 & 0.0000 \\
INS & 0.039768 & 0.0093 \\
\hline
\end{tabular}

Based on table 6. can be seen the results of the $t$ statistical test for each variable. The statistical test $t$ shows that the coefficient value of the variable institutional ownership (INS) is equal to 0.039768 (positive). This figure shows a positive relationship between institutional ownership and dividend payout (DPR). Judging from the value of institutional ownership probability of 0.0093 
$<0.05$, which means institutional ownership has a significant effect on the dependent variable which is proxied by a dividend payout ratio (DPR). This is in accordance with the sound of the first alternative hypothesis "institutional ownership in the company has positive effect on dividend payout policy "thus the hypothesis $\left(\mathrm{Ho}_{1}\right)$ is accepted.

Political connection (PCON) has a positive and significant effect on the dependent variable which is proxied by a dividend payout ratio (DPR), this can be seen from the PCON variable significance level of $0.0000<0.05$ with a regression coefficient value of 0.042068 (positive). Therefore, it can be concluded that there is a positive and significant influence between political connections with dividend payment policies (DPR), so that the second alternative hypothesis $\left(\mathrm{Ho}_{2}\right)$ which reads "political connections owned by companies adds to the (positive) dividend payment policy" or $\left(\mathrm{Ho}_{2}\right)$ is accepted.

\section{CONCLUSION AND RECOMMENDATION}

The selection of institutional ownership variables that are linked to dividend payment policies based on agency theory in this study is appropriate. This can be proven by the results of research that has been done, that the percentage of institutional ownership can have a positive influence on company policy in dividend payments. The selection of political connection variables to examine differences in company policy in dividend payments in this study is appropriate. Based on agency theory that explains the working relationship between principals and agents and the existence of agency conficts in it, the existence of external factors such as political connections can also influence.

The use of the political connection variable is rarely used in research related to dividend payment policies. It is hoped that this research can become a reference and further research can be carried out by sampling from one sector at a time, so that it is more focused.

\section{REFERENCES}

Abiprayu, K. B., \& Wiratama, B. (2016). Does CEO'S Hubris Affecting Dividends Payout? Jurnal Dinamika Manajemen, 7(1), 66-75.

Ahmad, G. N., \& Wardani, V. K. (2014). the Effect of Fundamental Factor to Dividend Policy: Evidence in Indonesia Stock Exchange. International Journal of Business and Commerce, 4(2), 14-25.

Anita, A \& Yulianto, A. (2016). Pengaruh Kepemilikan Manajerial dan Kebijakan Dividen ter- hadap Nilai Perusahaan. Management Analysis Journal, 5(1), 17-23.

Ardiansari, A., \& Saputra, A. (2015). Capital Market's Reaction towards 2014 Working Cabinet Announcement (Indonesian Case Study). Jurnal Dinamika Manajemen, 6(1), 62-72.

Aswadi, E., Zain, M. M., \& James, K. (2009). Institutional Investors, Political Connection and $\mathrm{Au}$ dit Quality in Malaysia. Emerald Article.

Keown, Arthur J, et al. 2008. Manajemen Keuangan. Salemba Empat, Jakarta.

Cahyaningdyah, D., \& Ressany, D. (2012). Pengaruh Kebijakan Manajemen Keuangan terhadap Nilai Perusahaan. Jurnal Dinamika Manajemen, $3(1), 20-28$.

Cooper, M. J., Gulen, H., \& Ovtchinnikov, A. V. (2010). Corporate Political Contributions and Stock Returns, The Journal of Finance. 67(2), 687-724.

Eckbo, E., \& Verma, S. (1994). Corporate Managerial Share Ownership, Voting Power, and Cash Dividend Policy. Journal of Corporate Finance, 1, 33-62.

Erfiana, D., \& Ardiansari, A. (2016). Pengaruh Masalah Keagenan, Kebijakan Dividen, dan Variabel Moderasi Growth Opportunity terhadap Nilai Perusahaan. Management Analysis Journal, 5(3), 244-256.

Firth, M., Gao, J., Shen, J., \& Zhang, Y. (2016). Institutional Stock Ownership and Firms' Cash Dividend Policies : Evidence from China. Journal of Banking Finance, 65, 91-107.

Ghozali, Imam dan Dwi Ratmono. (2013). Analisis Multivariat dan Ekonometrika: Teori, Konsep dan Aplikasi dengan Eviews 9. Semarang: Badan Penerbit Universitas Dipongoro.

Goldman, E., Rocholl, J., \& So, J. (2009). Do Politically Connected Boards Affect Firm Value. Review of Financial Studies, 22(6), 2331-2360.

Goldman, E., Rocholl, J., \& So, J. (2013). Politically Connected Boards of Directors and The Allocation of Procurement Contracts. Review of Finance, 17(5), 1617-1648.

Grinstein, Y., \& Michaely, R. (2005). Institutional Holdings and Payout Policy. The Journal of Finance, 60(3).

Han, K. C., Lee, S. H., \& Suk, D. Y. (1999). Institutional Shareholders and Dividends. Journal of Financial and Strategic Decisions, 12(1), 53-62.

Jannah, Roikhatul \& Khoiruddin, Moh. (2017). Peran Financial Distress Memediasi Kepemilikan Institusional, Kepemilikan Manajerial terhadap Return Saham. Management Analysis Journal, 6(3).

Johnson, S., \& Mitton, T. (2003). Cronyism and Capital Controls : Evidence from Malaysia. Journal of Financial Economics, 67(2003), 351-382.

McKnight, P. J., \& Weir, C. (2009). Agency Costs, Corporate Governance Mechanisms and Ownership Structure in Large UK publicly Quoted Companies: a Panel Data Analysis. Quarterly Review of Economics and Finance, 49(2), 139-158. 
Michael C. Jensen. (1986). Agency Costs of Free Cash Flow, Corporate Finance, and Takeovers Agency Costs of Free Cash Flow, Corporate Finance, and Takeovers. American Economic Review, 76(2), 323-329.

Miller, Merton \& Modligiani, F. (1961). Dividend Policy, Growth, and the Valuation of Shares. The Journal of Business, 34(4), 411-433.

Murhadi, W. R. (2010). Study on Dividend Policy : Antecedent and its Impact on Share Price., (25596).

Prasetyo, T. (2013). Dividen, Hutang dan Kepemilikan Institusional di Pasar Modal Indonesia: Pengujian Teori Keagenan. Jurnal Dinamika Manajemen, 4(2), 10-22.

Pratiwi, R., \& Yulianto, A. (2016). Pengaruh Struktur dan Komisaris Independen terhadap Biaya Keagenan. Management Analysis Journal, 5(3), 215-228.

Ridloah, Siti. (2010). Faktor Penentu Struktur Modal: Studi Empirik pada Perusahaan Multifinansial. Jurnal Dinamika Manajemen, 1(2), 144-153.

Roberto, M. A. (2002). Making Difficult Decisions in Turbulent Times. Ivey Business Journal, 66(3), 14.

Sari, Lupita \& Wijayanto, Andhi. (2015). Pengaruh Keputusan Investasi, Pendanaan, dan Dividen terhadap Nilai Perusahaan dengan Risiko Sebagai Variabel Mediasi. Management Analysis
Journal, 4(4), 281-291.

Setiawan, E. (2014). Analisis Pengaruh Ekspropriasi dan Koneksi Politik terhadap Kebijakan Dividen Tunai Perusahaan. Universitas Indonesia.

Shapiro. 1991. "Analisis Pengaruh Return on Equity, Insider Ownership, Investment Opportunity Set, Firm Size, Cash Flow, dan Debt Ratio terhadap Dividend Payout Ratio (Studi Empiris Perusahaan Manufaktur di BEI Periode 20042007)". Skripsi Ekonomi Akuntansi, Universitas Diponegoro.

Su, Z., Fung, H., Huang, D., \& Shen, C. (2014). Cash dividends, expropriation, and political Connections : Evidence from China. International Review of Economics and Finance, 29, 260-272.

Vermonte, P. J. 2012. Mendanai Partai Politik: Problem dan Beberapa Alternatif Solusinya. Analisis CSIS, 31(1), 82-94.

Yulianto, A., Suseno, D. A., \& Widiyanto, W. (2016). Testing Pecking Order Theory and Trade Off Theory Models in Public Companies in Indonesia. International Journal of Economic Perspectives, 10(4), 21-28.

Yulianto, A., Kiswanto, W., \& Yulianto, A. (2014). Linear and Non-linear Approaches in Testing Managerial Ownership on the Firm Value: Evidence Indonesian Firms. IOSR Journal of Business and Management (IOSR-JBM), 16(9), 1-5. 